\title{
Fecal pollution indicators removal by a vertical Multi-Soil- Layering system in domestic wastewater in Morocco
}

\author{
Aziz Taouraout ${ }^{1,2, *}$, Abdelkader Chahlaoui ${ }^{2}$, Driss Belghyti ${ }^{1}$, Imane Taha $^{2}$, Driss Bengoumi ${ }^{2}$, and Rachid Bouamri ${ }^{3}$ \\ ${ }^{1}$ Laboratory of Agrophysiology, Biotechnology, Environment and Qualities, Faculty of Sciences, University IbnTofail of Kenitra, BP: \\ 133, 14000 Kenitra Morocco. \\ ${ }^{2}$ Laboratory of Natural Resources Management and Development Team, Health and Environment, Faculty of Science, Moulay Ismail \\ University Meknes, Morocco. \\ ${ }^{3}$ Agroecology and Environment Team, National School of Agriculture, Moulay Ismail University Meknes, Morocco
}

\begin{abstract}
The aim of this study is to evaluate the ability of the vertical Multi-Soil-Layering filter (V-MSL) to remove indicators of fecal pollution from domestic wastewater under Moroccan conditions. To do this, a V-MSL filter measuring $20 \mathrm{~cm}$ deep, $60 \mathrm{~cm}$ wide, $78 \mathrm{~cm}$ high was installed near the guardian's house of the Razi's middle school in Meknes to treat domestic wastewater. Three hydraulic loads $\left(250 \mathrm{~L} / \mathrm{m}^{2} / \mathrm{day}, 350\right.$ $\mathrm{L} / \mathrm{m}^{2} /$ day and $500 \mathrm{~L} / \mathrm{m}^{2} /$ day) were tested. This filter showed an average reduction of $(97.5 \pm 0.3) \%,(97.7 \pm$ $0.4) \%$ and $(96.0 \pm 0.7) \%$, for total coliforms, fecal coliforms and fecal streptococci, respectively. The performance of the filter was not affected a lot when changing the hydraulic head from $250 \mathrm{~L} / \mathrm{m}^{2} /$ day to 500 $\mathrm{L} / \mathrm{m}^{2} /$ day. The bacterial load concentrations at the filter outlet are slightly higher than the WHO recommended standard $(1000 \mathrm{CFU} / 100 \mathrm{~mL})$ for reuse of wastewater in irrigation. To remedy this situation, we recommend the adoption of the principle of treatment of excreta at the source by the use of dry toilets and the treatment of gray water only by the V-MSL filter.
\end{abstract}

\section{Introduction}

In rural areas of Morocco, the population generally uses traditional autonomous drainage systems to get rid of black water and practices the direct discharge of gray water into nature without treatment [1]. With the increase in the supply of drinking water in recent years $(97 \%)$, the amount of wastewater generated is very large. In addition, open defecation remains the only way for the population without toilets [1-2]. These practices still present a major risk for public health and the environment; exposing many people to infection and dangerous diseases [3-5]. Indeed, human excrement can contain pathogens such as bacteria and parasites capable of causing diarrheal diseases (cholera, typhoid, etc.) [6].

The treatment of wastewater in these areas requires particular attention in the choice of purification technique to be used [7]. In these areas, wastewater treatment system strategies are needed which are environmentally, socially and economically sustainable [8-9]. Currently, a sustainable approach that holds interesting potential for decentralized sewage treatment is multi-soil-layering (MSL) system [10]. The first MSL system was developed in Japan (1990), to treat wastewater [11-12]. This system was also tested in China, Thailand and the USA, for the treatment of domestic wastewater [13], polluted river water [14], and leachate [15] etc. The MSL system is typically composed of soil mixture blocks (SMB) arranged in a brick-like pattern and surrounded by water-permeable particles, such as zeolite and gravel [10]. This system is economic because it can be developed mainly from local resources such as soil, sawdust, iron, charcoal, gravel and alternative materials and required only a small land area [9,16-19]. According to Guan et al., [20], this new system was less prone to clogging supporting a higher hydraulic load rate (HLR). Some authors suggested that effective contact between the wastewater and SMB increased the MSL performance [14, 21].

As a promising treatment technology and a costeffective solution for sustainable water management, it is essential to evaluate its performance in Moroccan conditions. To do this, a pilot-scale of vertical MultiSoil-Layering system (V-MSL) was designed to treat domestic wastewater next to a single house. The aim of this study is to evaluate the ability of the V-MSL system to remove the fecal pollution indicators from domestic wastewater under three hydraulic loading rates $(250$ $\mathrm{L} / \mathrm{m}^{2} /$ day, $350 \mathrm{~L} / \mathrm{m}^{2} /$ day and $500 \mathrm{~L} / \mathrm{m}^{2} /$ day) in Moroccan conditions.

\section{Materiel and methods}

\subsection{Description of treatment system}

The pilot-scale system used in this study is a vertical Multi-Soil-Layering filter (V-MSL) measuring $20 \mathrm{~cm}$ deep, $60 \mathrm{~cm}$ wide, $78 \mathrm{~cm}$ high with a feeding tank $(100 \mathrm{~L})$ used to store prescreened wastewater from the

Corresponding author: aziz.taouraout@uit.ac.ma 
inlet of the household wastewater using submersible pump. This is installed next to the guardian's house at Razi's middle school (Meknes, Morocco). Three hydraulic loads were tested (HLR1:250 L/m²/day, HLR2:350 L/m²/day and HLR3:500 L/m $/ \mathrm{m}^{2} /$ day). The characteristics of this system are illustrated in figure 1. The choice of materials used in our MSL system, is mainly related to their availability and cost in Morocco. Indeed, the permeable layer (PL) is composed by the gravel with a diameter between 3 to $5 \mathrm{~mm}$. Their role is to improve the water distribution and reduce the risk of clogging. While the SMBs measuring $20 \mathrm{~cm}$ (L) $\mathrm{x}$ $16.5 \mathrm{~cm}(\mathrm{~W}) \times 4 \mathrm{~cm}(\mathrm{H})$, are composed by $60 \%$ of soil, $10 \%$ of charcoal, $10 \%$ of iron sawdust and $20 \%$ of wood sawdust.

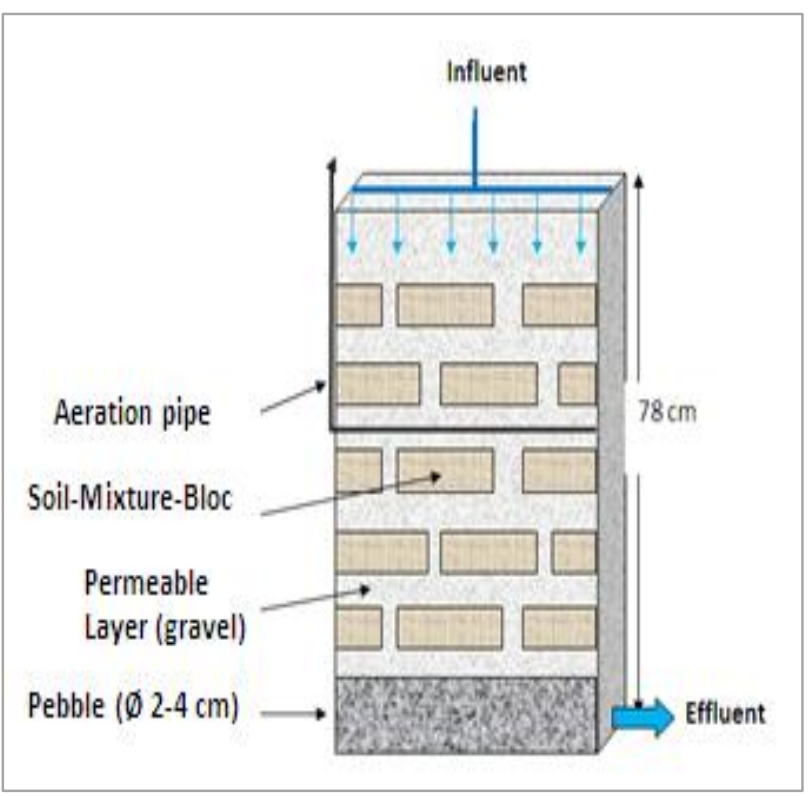

Fig. 1. Schematic representation of Vertical Multi-SoilLayering (V-MSL)

The filling of the filter is done in the following order: the first layer ( $20 \mathrm{~cm}$ thick) is composed by the pebbles followed by the first permeable layer $(5 \mathrm{~cm}$ thick of gravel) followed by the first layer of bricks (SMBs); the alternation of the permeable layers and the brick layers succeed one another until the sixth permeable layer. The bricks are arranged horizontally with a space of $5 \mathrm{~cm}$ between them.

\subsection{Analysis of fecal indicator bacteria in influent and effluent}

After the stabilization period (three months), samples of raw and treated water were collected at the same time each month (from June 2017 until April 2018) to perform bacteriological analyzes. These samples were collected in sterile $500 \mathrm{~mL}$ glass vials and stored in a refrigerated cooler $\left( \pm 4^{\circ} \mathrm{C}\right)$. These analyzes were carried out in the BETA laboratory of Dr. BENGOUMI Driss in Meknes. The following table summarizes the various bacteriological parameters analyzed as well as the method undertaken (Table 1).
Table 1. Bacteriological parameters and methods of analysis

\begin{tabular}{|c|c|c|}
\hline Parameter & Technique & Reference \\
\hline $\begin{array}{l}\text { Total } \\
\text { coliforms } \\
\text { (TC) }\end{array}$ & $\begin{array}{l}\text { Count by membrane } \\
\text { filtration }(0.45 \mu \mathrm{m}) \text { on } \\
\text { Tergitol agar with TTC } 7 \\
24 \text { hour Agar at } 37^{\circ} \mathrm{C} .\end{array}$ & $\begin{array}{l}\text { ISO 9308- } \\
1: 2014 \\
{[22]}\end{array}$ \\
\hline $\begin{array}{l}\text { Fecal } \\
\text { coliforms } \\
\text { (FC) }\end{array}$ & $\begin{array}{l}\text { Count by membrane } \\
\text { filtration }(0.45 \mu \mathrm{m}) \text { on } \\
\text { Tergitol agar with TTC } 7 \\
24 \text { hour Agar at } 44^{\circ} \mathrm{C} \\
\end{array}$ & $\begin{array}{l}\text { ISO 9308- } \\
1: 2014 \\
{[22]}\end{array}$ \\
\hline $\begin{array}{l}\text { Fecal } \\
\text { streptococci } \\
\text { (FS) }\end{array}$ & $\begin{array}{l}\text { Count by membrane } \\
\text { filtration }(0.45 \mu \mathrm{m}) \text { on } \\
\text { Slanetz and Bartly agar } \\
24 \mathrm{~h}-48 \mathrm{~h} \text { at } 37^{\circ} \mathrm{C}\end{array}$ & $\begin{array}{l}\text { ISO 7899- } \\
2: 2000 \\
{[23]}\end{array}$ \\
\hline
\end{tabular}

The statistical data treatment was carried out by software: Excel 2010 and SPSS 20. Analysis of variance (ANOVA) was used to evaluate the significant difference between the raw water samples and the treated water as well as between the different hydraulic loading rates used.

\section{Results and discussions}

\subsection{Concentrations of the fecal pollution indicators}

The mean, maximum and minimum concentrations of the fecal pollution coliforms in domestic wastewater to be treated were respectively, $(1.31 \pm 0.15) \times 10^{6}$ $\mathrm{CFU} / 100 \mathrm{~mL}, 1.53 \times 10^{6} \mathrm{CFU} / 100 \mathrm{~mL}$ and $1.03 \times 10^{6}$ CFU/100 mL for total coliforms, $(1.05 \pm 0.19) \times 10^{6}$ $\mathrm{CFU} / 100 \mathrm{~mL}, 1.33 \times 10^{6} \mathrm{CFU} / 100 \mathrm{~mL}$ and $6.80 \times 10^{5}$ CFU / $100 \mathrm{~mL}$ for fecal coliforms and $(1.62 \pm 0.41) \times 10^{5}$ CFU / $100 \mathrm{~mL}, 2.53 \times 10^{5} \mathrm{CFU} / 100 \mathrm{~mL}$ and $1,17 \times 10^{5}$ CFU / $100 \mathrm{~mL}$ for fecal streptococci (Table 2).

Table 2. Concentrations (CFU/100 mL) and reduction (\%) of the fecal pollution indicators by the H-MSL filter

\begin{tabular}{|c|c|c|c|c|c|}
\hline & & Mean & SD & Max. & Min. \\
\hline \multirow{3}{*}{$\mathrm{TC}$} & Inflow & $\begin{array}{l}1,31 \\
\times 10^{6}\end{array}$ & $\begin{array}{l}1,55 \\
\times 10^{5}\end{array}$ & $\begin{array}{l}1,53 \\
\times 10^{6}\end{array}$ & $\begin{array}{r}1,03 \\
\times 10^{6}\end{array}$ \\
\hline & V-MSL & $\begin{array}{l}3,20 \\
\times 10^{4}\end{array}$ & $\begin{array}{l}1,40 \\
\times 10^{3}\end{array}$ & $\begin{array}{l}3,42 \\
\mathrm{x} 10^{4}\end{array}$ & $\begin{array}{l}2,93 \\
\times 10^{4}\end{array}$ \\
\hline & Removal \% & 97,5 & 0,3 & 97,9 & 96,9 \\
\hline \multirow{3}{*}{$\mathrm{FC}$} & Inflow & $\begin{array}{l}1,05 \\
\times 10^{6}\end{array}$ & $\begin{array}{l}1,94 \\
\times 10^{5}\end{array}$ & $\begin{array}{l}1,33 \\
\times 10^{6}\end{array}$ & $\begin{array}{r}6,80 \\
\times 10^{5}\end{array}$ \\
\hline & V-MSL & $\begin{array}{r}2,36 \\
\times 10^{4} \\
\end{array}$ & $\begin{array}{r}2,08 \\
\times 10^{3} \\
\end{array}$ & $\begin{array}{r}2,67 \\
\times 10^{4} \\
\end{array}$ & $\begin{array}{r}1,95 \\
\times 10^{4}\end{array}$ \\
\hline & Removal \% & 97,7 & 0,4 & 98,2 & 96,6 \\
\hline \multirow{3}{*}{ FS } & Inflow & $\begin{array}{r}1,62 \\
\times 10^{5} \\
\end{array}$ & $\begin{array}{l}4,11 \\
\times 10^{4}\end{array}$ & $\begin{array}{r}2,53 \\
\times 10^{5} \\
\end{array}$ & $\begin{array}{l}1,17 \\
\times 10^{5}\end{array}$ \\
\hline & V-MSL & $\begin{array}{r}6,27 \\
\times 10^{3} \\
\end{array}$ & $\begin{array}{r}1,00 \\
\times 10^{3} \\
\end{array}$ & $\begin{array}{r}8,40 \\
\times 10^{3} \\
\end{array}$ & $\begin{array}{r}4,94 \\
\times 10^{3} \\
\end{array}$ \\
\hline & Removal \% & 96,0 & 0,7 & 97,02 & 94,9 \\
\hline
\end{tabular}

(TC: total coliforms; FC: fecal coliforms; FS: fecal streptococci; SD: Standard Deviation) 
The variability of bacterial concentration during the study period is mainly linked to the quality of the organic load of the wastewater to be treated and the hydraulic loading rates applied (Fig. 2).

After treatment, the average concentrations of these fecal indicators were $(3.20 \pm 0.14) \times 10^{4} \mathrm{CFU} / 100 \mathrm{~mL}$, $(2.36 \pm 0.21) \times 10^{4} \mathrm{CFU} / 100 \mathrm{~mL}$ and $(6.27 \pm 1.00) \times 10^{3}$ CFU / $100 \mathrm{~mL}$ for total coliforms, fecal coliforms and fecal streptococci, respectively (Table 2 and Fig. 2). The V-MSL filter ensured an average reduction of $(97.5 \pm$ $0.3) \%,(97.7 \pm 0.4) \%$ and $(96.0 \pm 0.7) \%$, for TC, FC and FS, respectively (Table 2).

The ANOVA test shows that there is a very highly significant difference between raw water and treated water regarding the average bacterial loads of TC, FS and FC (Table 4).

Table 3. Analysis of variance (ANOVA) of bacterial concentrations between inflow and outflow

\begin{tabular}{|c|c|c|c|c|}
\hline Parameter & $\begin{array}{c}\text { Inflow } \\
(\mathrm{I})\end{array}$ & $\begin{array}{c}\text { Outflow } \\
(\mathrm{J})\end{array}$ & Difference (I-J) & $\mathrm{P}<0.001$ \\
\hline TC & DWW & V-MSL & $1274460,8^{* * *}$ &, 000 \\
\hline FS & DWW & V-MSL & $155541,5 * * *$ &, 000 \\
\hline FC & DWW & V-MSL & $1029429,3 * * *$ &, 000 \\
\hline
\end{tabular}

*** Signification at $\mathrm{p}<0,001 \quad$ DWW: domestic wastewater $\mathrm{I}$ : concentration of parameter in inflow $\mathrm{J}$ : concentration of parameter in outflow

\subsection{Reduction of fecal pollution indicators depending on the hydraulic load used and the season}

The average removal rates of fecal pollution during the study period under the three hydraulic loads tested (HLR1, HLR2 and HLR3) were respectively 97.40\%, $97.51 \%$ and $97.67 \%$ (for the TC), $97,54 \%, 97.76 \%$ and $97.80 \%$ (for FC) and $96.57 \%, 96.13 \%$ and $95.32 \% \%$ (for FS) (Fig. 2). Despite the differences in the reduction rates reported between the hydraulic loads applied to the filter, the ANOVA test did not show any significant difference between these rates for the TC $(p>0.21)$, FS $(p>0.45)$ and FC $(p>0.24)$. The average removal rates of fecal pollution according to the seasons (summer to spring) were $97.4 \%, 97.5 \%, 97.6 \%$ and $97.7 \%$, respectively, for $\mathrm{TC} ; 97.2 \%, 97.8 \%, 97.8 \%$ and $98.0 \%$ for FC and $96.6 \%, 96.1 \%, 95.8 \%$ and $95.5 \%$ for FS (Fig. 2).

Despite the differences in reduction rates reported between seasons, the ANOVA test did not show any significant difference between these rates for TC $(p>0.5)$, FS $(p>0.7)$ and FC $(p>0.1)$; however, this test revealed a significant difference between summer and spring for FC.

In general, the V-MSL filter has shown significant efficiency in eliminating fecal pollution indicators and it has also shown some stability in terms of performance during all seasons.
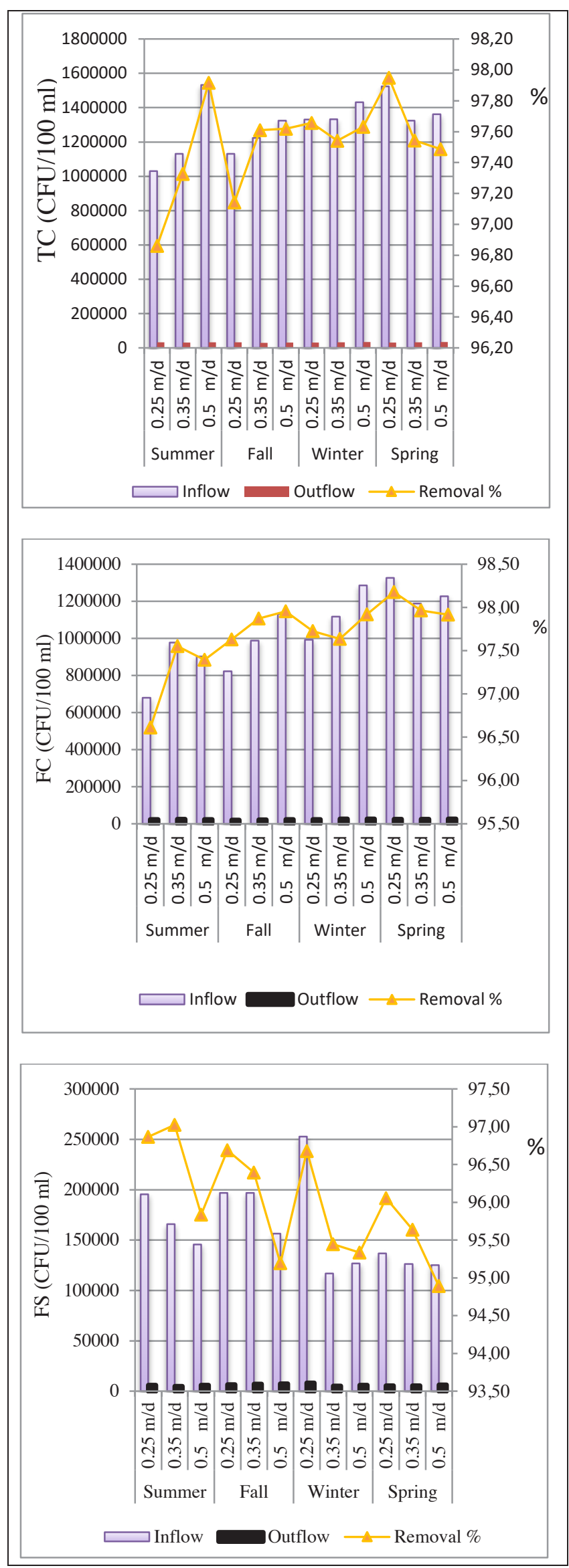

Fig. 21. Reduction of fecal pollution indicators depending on the hydraulic load and season 
The high removal rates recorded by our V-MSL system can be explained by the high dissolved oxygen concentrations within the filter during the study period, as well as the water temperature which was relatively optimal throughout the study period (especially in summer and fall).

The mean elimination of fecal pollution indicators ranged from $1.24 \pm 0.18$ to $1.64 \pm 0.07 \log$ units (Table 4). Indeed, the total coliforms were reduced by $1.61 \pm 0.05$ $\log$ units, $1.64 \pm 0.07 \mathrm{log}$ units for fecal coliforms, and $1.40 \pm 0.08 \log$ units for fecal streptococci. These results are better than those reported by El Hamouri et al. [24] on horizontally constructed wetland, to those obtained by Eturki et al., [25] with their infiltration and percolation system (0.7 logarithmic units for fecal coliforms), to those of Torrens et al. [26] on vertical constructed wetland and those of Latrach et al. [27].

Table 4. Reduction of fecal bacterial indicators expressed by $\log 10$ per $100 \mathrm{~mL}$ during the study period

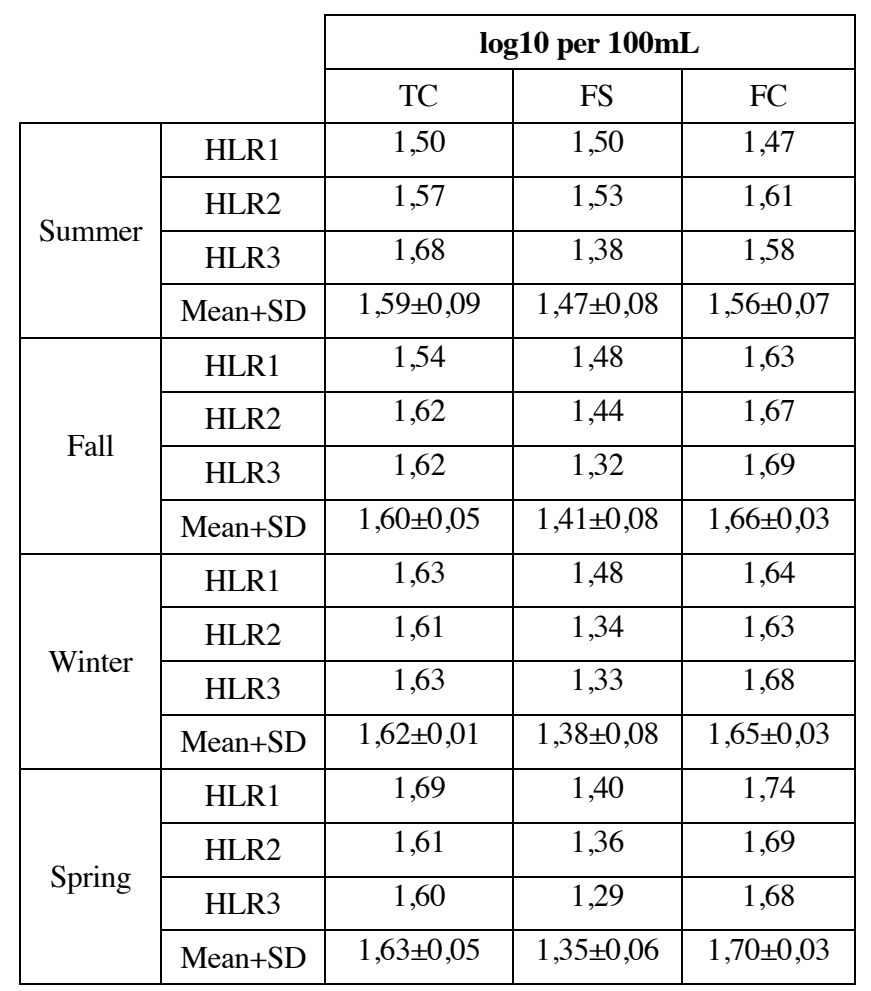

On the other hand, our results corroborate those of Morató et al. [28] who obtained removal rates in the order of 1.2-2.2 $\log$ units for total coliforms, 1.4-2.2 log units for fecal streptococci in their planted constructed wetland filters.

Almost similar results were obtained by Arias et al. [29] concerning the abatement of TC and FC in two-stage of vertical constructed wetland filters with pretreatment and post-treatment in a calcite filtration unit in Denmark. They reported that the first bed of their system had the highest efficiency with $1.5 \mathrm{log}$ and 1.7 for TC and FC, respectively. However, the results reported by Latrach et al. [19] are clearly better than ours with their hybrid system combining MSL technology and sand filters, they obtained reduction rates of the order of 4.13 and 4.47 logarithmic units for the reduction of coliforms. Despite the performance given by their hybrid system, these authors reported that the sand filters were clogged after two months of operation with hydraulic loads of 100, 200 and $400 \mathrm{~L} / \mathrm{m}^{2} /$ day.

The moderate efficiency obtained by the present study could be due, on the one hand, to the high porosity of the gravel which is used as a permeable layer (diameter between 3 and $5 \mathrm{~mm}$ ); on the other hand, to the hydraulic load used which is relatively high and to the short residence time of the water to be treated within our filter (approximately one hour). The same observation is reported by Stevik et al. [30] and Ausland et al. [31] who concluded that germ infiltration is influenced by the physical characteristics of the filter substrate and by the hydraulic loading rate used. In the same context, Bomo et al. [32] showed a significant improvement in the elimination of pathogenic bacteria in the case of fine sand $(\mathrm{d} 10=0.25)$ rather than coarse $(\mathrm{d} 10=0.86)$ filters. Additionally, Vacca et al. [33] concluded that the grain size of the filter substrate affects the elimination of bacteria. Torrens et al. [26] also confirmed that bacterial reduction in porous media is provided by filtration and adsorption of the bacterial load to the filter substrate. Along the same lines, Stevik et al. [30]; Garcia et al. [34] have shown that fine materials such as sand, clay and silt (very fine pores) act as a filtration system for bacteria. This could be explained by the hydraulic retention time which is high in filters with fine substrate compared to filters with coarse substrate.

Therefore, the hydraulic residence time appears to be a crucial parameter for the performance of the system. On the other hand, the retention time of wastewater in the filtration system increases with the decrease in the applied hydraulic loading rate, giving the system sufficient time to adsorb, react and remove organic pollutants and the bacterial load from the wastewater [9].

Filtration and adsorption could be the first bacteria elimination mechanisms in the MSL system followed by the other reduction process such as predation by other organisms (eg, protozoa, nematodes, etc.) and natural death. In fact, predation by the intervention of protozoa, nematodes and bacteriophages has been proven to play an essential role in the elimination of germs indicative of fecal pollution in vertical flow filters by several studies [35-39].

\section{Conclusion}

The V-MSL used in this study was able to achieve the reductions of the fecal pollution indicators: $(97.5 \pm 0.3) \%$, $(97.7 \pm 0.4) \%$ and $(96.0 \pm 0.7) \%$, for TC, FC and FS, respectively. Generally, the abatement of these indicators decreased with increasing of hydraulic loading rates. However, the ANOVA test did not show any significant difference between the three hydraulic loading rates tested at $\mathrm{p}<0.05$. On the other hand, despite the difference reduction rates reported between seasons, this test did not show any significant at $p<0.05$, except between summer and spring for FC.

The bacterial load concentrations at the filter outlet are slightly higher than the WHO recommended standard 
(1000 CFU / 100mL) for reuse of wastewater in irrigation. To remedy this situation, we recommend the adoption of the principle of treatment of excreta at the source by the use of dry toilets and the treatment of gray water only by the V-MSL filter.

Acknowledgements. Our thanks to the principal and school safety agent (Razi, Meknes) for their assistance.

\section{References}

1. A. Taouraout, A. Chahlaoui, D. Belghity, M. Najy; A. Kharroubi (2018). The socio-cultural acceptance of EcoSan latrines (UDDTs) in rural areas of Morocco. SCA '18, October 10-11, 2018, Tetouan, Morocco (C) 2018 Association for Computing Machinery. ACM ISBN 978-1 -4503-65628/18/10...\$15.00. https://doi.org/10.1145/3286606.3286815

2. WHO/UNICEF. Drinking Water,Sanitation and HygieneUpdate and SDG Baselines. Report (2017).

3. J.N. Galloway, F.J. Dentener, D.G. Capone, E.W. Boyer, R.W. Howarth, S.P. Seitzinger, G.P. Asner, C.C. Cleveland, P.A. Green, E.A. Holland, Nitrogen cycles: past, present, and future. Biogeochemistry; 70:153-226 (2004).

4. RT. Watson, AH. Zakri,. Living beyond our means. Natural assets and human well-being. Statement from the Board. Millennium Ecosystem Assessment (2008).

5. United Nations. Agenda items 5, 6 and 18 (a) High level segment High-level political forum on sustainable development, convened under the auspices of the Economic and Social Council Economic and environmental questions: sustainable development Progress towards the Sustainable Development Goals. Report of the Secretary-General (2016).

6. OMS, 2006. Directives de l'OMS sur la réutilisation des eaux usées, des excréta et des eaux grises.

7. L. Latrach, M. Belloulid, T. EL Moussaoui, S. Bougarrani, S. Elfanssi et O. Elassri, Assainissement rural au Maroc : situation, réalisations et perspectives. EWASH \& TI Journal, 2018 Volume 2 Issue 3, Page 63-72 Environmental and Water Sciences, Public Health \& Territorial Intelligence. ISSN Electronic Edition : 2509 (2018).

8. M. Mahi, K. Lamzouri, S. Ouatar, A. Hadraoui, E. Bartali, L. Mandi, J. International Journal of Computer Fngineering and Information Technologyz (2015) 34- 4r.

9. A. Taouraout, A. Chahlaoui, D. Belghyti, I. Taha, K. Ouarrak, , R. Sammoudi,. Hydraulic load rates effect on the performance of Horizontal Multi-SoilLayering to treat domestic wastewater in rural areas of Morocco. J.M.E.S., Volume 10, Issue5, Page 422430 (2019).

10. C.J. An, E. Mcbean, G.H. Huang, Y. Yao, P. Zhang, X.J. Chen, Y.P. Li, Multi-Soil-Layering Systems for
Wastewater Treatment in Small and Remote Communities; 27:131-144 (2016). https://doi.org/10.3808/jei.201500328

11. T. Wakatsuki, H. Esumi, S. Omura, High performance and $N \& P$ removable on-site domestic waste water treatment system by Multi-Soil-Layering method. Water Sci. Technol., 27, 31-40 (1993).

12. T. Masunaga, K. Sato, J. Mori, M. Shirahama, H. Kudo, T. Wakatsuki, Characteristics of wastewater treatment using a multi-soil-layering system in relation to wastewater contamination levels and hydraulic loading rates. Soil Sci. Plant Nutr.; 53:215-223 (2007).

13. W. Luo, C. Yang, H. He, G. Zeng, S. Yan, and Y. Cheng, Novel two-stage vertical flow biofilter system for efficient treatment of decentralized domestic wastewater. Ecol. Eng., 64, 415-423 (2014). http://dx.doi.org/10.1016/j.ecoleng.2014.01.011

14. T. Masunaga, K. Sato, T. Zennami, S. Fujii, T. Wakatsuki, Direct treatment of polluted river water by the multi-soil-layering method. Journal of Water and Environment Technology; 1:97-104 (2003). http:// dx.doi.org/10.2965/jwet.2003.97

15. G.Yidong, X. Chen, S. Zhang, A. Luo, Performance of multi-soil-layering system (MSL) treating leachate from rural unsanitary landfills. Science of The Total Environment 420:183-90 (2012). DOI: $10.1016 /$ j.scitotenv.2011.12.057

16. P. Boonsook, S. Luanmanee, T. Attanandana, A. Kamidouzono, T. Masunaga, T. Wakatsuki, A comparative study of permeable layer materials and aeration regime on efficiency of multi-soil-layering system for domestic wastewater treatment in Thailand. Soil Sci. Plant Nutr., 49, 873-882 (2003).

17. X. Chen, A.C. Luo, K. Sato, T. Wakatsuki, T. Masunaga,. An introduction of a multi-soil-layering system: a novel green technology for wastewater treatment in rural areas. Water Environ. J., 23(4), 255-262 (2009). http://dx.doi.org/10.1111/j.17476593.2008.00143.x

18. K. Lamzouri, M. Mahi, S. Ouatar, E. Bartali, T. Masunaga, L. Latrach, L. Mandi, Application of Multi-soil-layering technique for wastewater treatment in Moroccan rural areas: study of the operation process for an engineering design. J.M.E.S. ; 7:579-585 (2016).

19. L. Latrach, N. Ouazzani, T. Masunaga, A. Hejjaj, K. Bouhoum, M. Mahi, L. Mandi, Domestic wastewater disinfection by combined treatment using multi-soil-layering system and sand filters (MSL-SF): A laboratory pilot study. Ecological Engineering, 91 (2016). https://doi.org/10.1016/j.ecoleng.2016.02.036

20. Y. Guan, D. Xu, X. Chen, A. Luo, H. Fang, and Y. Song, Flow patterns of multi-soil-layering systems. Desalination Water Treat., 52(22-24), 4165-4169 (2014). $\quad$ http://dx.doi.org/10.1080/19443994. $\underline{2013.801791}$

21. K. Sato, T. Masunaga, T. Wakatsuki, Characterization of treatment processes and 
mechanisms of COD, phosphorus and nitrogen removal in a multi-soil- layering system. Soil Sci. Plant Nutr. 51 (2), 213-221 (2005).

22. ISO 9308-1:2014, Qualité de l'eau - Dénombrement des Escherichia coli et des bactéries coliformes (Référence pour CT, CF et E. coli) Partie 1: Méthode par filtration sur membrane pour les eaux à faible teneur en bactéries (2014).

23. ISO 7899-2:2000, Qualité de l'eau - Recherche et dénombrement des entérocoques intestinaux (Référence pour SF) - Partie 2: Méthode par filtration sur membrane (2000).

24. B. El Hamouri, J. Nazih, J. Lahjouj, Subsurfacehorizontal flow constructed wetland for sewage treatment under Moroccan climate conditions, Desalination, 215, 153- $158 \quad$ (2007), doi:10,1016/j,desal,2006,11,018

25. S. Eturki, F. Ayari, H. Kallali, N. Jedidi, H. Ben Dhia, Treatment of rural wastewater (2012).

26. A. Torrens, P. Molle, C. Boutin, M. Salgot, Removal of bacterial and viral indicators in vertical flow constructed wetlands and intermittent sand filters, Desalination, 246, 169-178 (2009), doi:10,1016/j,desal,2008,03,050

27. L. Latrach, T. Masunaga, N. Ouazzani, A. Hejjaj, M. Mahiand, L. Mandi, Removal of bacterial indicators and pathogens from domestic wastewater by the multi-soil-layering (MSL) system. Soil Sci. Plant Nutr., 61(2), 337-346 (2015). http://dx.doi.org/10.1080/ 00380768.2014.974480

28. J. Morató, F. Codony, O. Sánchez, L. Martín Pérez, J. García, J. Mas, Key design factors affecting microbial community composition and pathogenic organism removal in horizontal subsurface flow constructed wetlands, Sci, Total Environ. 481,81-89 (2014),

29. C.A. Arias, A. Cabello, H. Brix, N. Johansen, Removal of indicator bacteria from municipal wastewater in an experimental two-stage vertical flow constructed wetland system, Water Science and Technology 48 (5), 35-41 (2003),

30. T.K. Stevik, K. Aa, G. Ausland, J.F. Hanssen, Retention and removal of pathogenic bacteria in wastewater percolating through porous media: a review, Water Research 38, 1355-1367 (2004).

31. G. Ausland, T.K. Stevik, J.F. Hanssen, JC.K. Hler, P.D. Jenssen, Intermittent filtration of wastewater removal of fecal coliforms and fecal streptococci, Water Res., 36, 3507- $3516 \quad$ (2002), doi:10,1016/S0043-1354(02)00060-X

32. A.M. Bomo, A. Husby, T.K. Stevik, J.F. Hanssen, Removal of fish pathogenic bacteria in biological sand filters, Water Res,, 37, 2618-2626 (2003), doi:10,1016/S0043-1354(03)00075-7

33. G. Vacca, H. Wand, M. Nikolausz, P. Kuschk, M. Ka"stner, Effects of plants and filter materials on bacteria removal in pilot-scale constructed wetlands, Water Research 39, 1361-1373 (2005),
34. J. Garci'a, D.P.L. Rousseau, J. Morato'. E. Lesage, V. Matamoros, J.M. Bayona, Contaminant removal processes in subsurface-flow constructed wetlands: a review, Critical Reviews in Environmental Science and Technology 40, 561-661 (2010),

35. M.B. Green, P. Griffin, J.K. Seabridge, D. Dhobie, , Removal of bacteria in subsurface flow wetlands, Water Science and Technology 35, 109-116 (1997).

36. O. Decamp, A. Warren, Bacterivory in ciliates isolated from constructed wetlands (reed beds) used for wastewater treatment, Water Res, 32, 1989-1996 (1998),

37. J. Pernthaler, Predation on prokaryotes in the water column and its ecological implications, Nat, Rev, Microbiol, 3, 537-546 (2005), http://dx, doi,org/10,1038/ nrmicro1180,

38. H. Wand, G. Vacca, P. Kuschk, M. Krüger, M. Ka"stner, Removal of bacteria by filtration inplanted and non-planted sand columns, Water Research 41, 159-167 (2007),

39. J.T. Jasper, M.T. Nguyen, Z.L. Jones, N.S. Ismail, D.L. Sedlak, J.O. Sharp, R.G. Luthy, A.J. Horne, K.L. Nelson, Unit process wetlands for removal of trace organic contaminants and pathogens from municipal wastewater effluents, Environ, Eng, Sci, 30, 421-436 (2013), http://dx,doi,org/10,1089/ees, 2012,0239 